Csaba Lentner

\title{
FROM AN ACTIVE STATE-LED FINANCIAL POLICY TO AN ACTIVE STATE-LED FINANCIAL POLICY - A TAXONOMICAL OUTLINE OF HUNGARY'S PUBLIC FINANCES IN THE PAST THIRTY YEARS ${ }^{1}$
}

Csaba Lentner, Full Professor in Public Finance, Faculty of Governmental and International Studies, University of Public Service, lentner.csaba@uni-nke.hu

The aim of this study is to trace the three-decade-long market economy transition that has replaced the socialist planned economy in Hungary, a process which is divided into two parts by the author. He begins by outlining the harsh, neoliberal methodology of the transition, and the Hungarian fiscal practice which developed from it, built on the application of non-conventional instruments of active government regulation and fundamentally based on the Fundamental Law (Hungary's constitution) adopted in 2011, particularly its chapter on Public Finances and the cardinal laws pertaining to public finances. The study is a journey through time, encompassing three decades, demonstrating that the Achilles heel of the transition was its dependence on the basic conditions of the socialist planned economic system, which still exert an effect today. It provides an outline of the taxonomical elements of three, significantly different yet interrelated economic eras taking place in a Central European country in less than a century, and draws a macro-economic conclusion. The purpose of the study of more than three decades is to provide a historic set and, based on this, an outlook for the future for prognosis, which is especially important now at the time of Covid-19 problems.

KEYWORDS:

planned economy, harsh market economy transition, J M Keynes system, unorthodox method, Hungary

\footnotetext{
The work was implemented in the framework of project No. TKP2020-NKA-09, financed by the Thematic Excellence Program 2020 from the National Research Development and Innovation Fund. Made in the Széll Kálmán Public Finance Lab at the University of Public Service.
} 


\section{THE BASIS FOR A STILL INFLUENTIAL BASE DEPENDENCE: SOCIALIST PLANNED ECONOMY INFUSED WITH MARKET ELEMENTS}

Several Western theorists and the younger Hungarian generation have a perception of post-war Hungary as a country which applied a normative, Soviet-type planned economic system, together with the other Central and Eastern European countries. Undoubtedly, Hungary - due to the fate which befell it as a result of the Yalta Conference, determining the division of Europe after the war, and, in particular, its geopolitical position - was included in the Soviet sphere of interest and came under the auspices of the socialist world economic system, but in some important respects it deviated from the other socialist countries in its planned economic practice, and infused its conditions with market elements, for example in the reform attempt of 1955-1956, or the New Economic Mechanism launched in 1968 in particular. Although the basic elements of the Hungarian planned economy were built on state and cooperative ownership and the primacy of the people's economic plan, setting the frameworks of the system, the consideration of market aspects and the prevalence of a material interest appeared in a broad circle of companies owned by the socialist state, agricultural cooperatives and workers. The regulatory practice applied to the economy and, more importantly, the one-party control over it allowed for a stronger assertion of the material interests of employees (endogenous factors) to a certain extent. From the 1970s onwards, the rental (and small concession) ${ }^{2}$ of certain state- and cooperativeowned components was possible, which represented a rudimentary form of enterprise, allowing the establishment of economic work teams and the achievement of higher income positions. In 1962, at the $8^{\text {th }}$ Congress of the Hungarian Socialist Labour Party, it was announced that the socialist restructuring of agriculture, under which agricultural cooperatives and state farms had become common operating units, had finished. However, peasant members of the cooperatives were able to exercise some initiative in the form of small-scale farming they carried out, in close cooperation with and backed by largescale agriculture, while the employees of state farms were allotted some land for their own use. ${ }^{3}$ The system was built on the alloy of the peasants' diligence and a perceivable financial gain, which succeeded in enhancing the efficiency of the Hungarian agriculture. In the late 1970s, Hungarian agriculture was competing with the economies of scale of farms in North America.

At the same time, problems arose with this system. ${ }^{4}$ The success of Hungarian reforms was accompanied by internal, retrograde forces and the aversion and counter-interests

Small concessions were common primarily in catering, in case of shops and stores.

The Hungarian version of small-scale farming was inconceivable in the Soviet Union or for example in Romania.

4 A more detailed examination of the unsustainability of the socialist planned economy, can be found in the works of János Kornai. See, for example, János Kornai, 'A szocialista rendszer' [The Socialist Regime], in Kornai János válogatott munkái II [The Selected Works of János Kornai Vol. II] (Pozsony: Kalligram, 2012), 
of the Communist Party of the Soviet Union, since they could be perceived as challenging the essence and presumed efficiency of socialism; therefore, forces opposed to this change slowed the momentum of the model built on interior market elements, which was manifested in a lack of material interest, work indiscipline, an alienation towards social property, and a massive occurrence of negative tendencies. Starting from the 1970s, the planned economic system was able to guarantee full employment, free education and healthcare and further subsidies deriving from the paternalism of the system only by means of external loans. ${ }^{5}$ In the 1970s, it absurdly tried to achieve the general goal set by socialism, i.e. to exceed the capitalist way of production, by continuing its operation while relying on the loans of the capitalist world. By the time of the regime change, it had accumulated debts amounting to USD 21 billion. Exchange rates were unfavourable in relation to both the U.S. dollar and the transferable rouble. Even paying interest rates posed a problem. Hungarian society at this time, socialised to state paternalism and producing deteriorating performances in workplaces, did, however experience benefits from the loans provided by the Western world, albeit modest ones. A mindset was adopted in this era which remains influential to this day, according to which declining performance may (still) result in income growth and a higher standard of living. The approach and practice - still very much alive today - that loss-making companies can continue to operate as the state would help them out anyway emerged at this point. ${ }^{6}$ Furthermore, all this was possible both systematically and continuously. The draining effect of the arms race between the two global powers and the oil boom in the world market did not bring about a substantial correction or modernisation of the poorly operating Hungarian market, and as a result of the accumulation of all these shortcomings, the foundations of the system were shaken. By the late 1980s, a transformation of an open market economy nature and an economic regime change, looking towards external resources had started to take place.

\section{TAXONOMY OF THE MARKET ECONOMY TRANSITION}

By the late 1980s Hungary was suffering from chronic shortages of working capital and portfolio capital, and consequently, there was a growing need for these missing funds. As a result of the opening of national borders and the population becoming familiar with the Western standard of living and way of life, demand for high-quality products and services had skyrocketed. It was necessary to re-integrate the workers laid off in hundreds

670; János Kornai, 'A puha költségvetési korlát' [The Soft Budget Constraint], in Kornai János válogatott munkái IV [The Selected Works of János Kornai Vol. IV] (Pozsony: Kalligram, 2014), 383.

5 An interesting example from the past: basically, the same derivative of hydrocarbon (gasoline) was used for heating provided by oil stoves, widely used from the 1970s, and the diesel motor vehicles used by companies. However, the fuel oil product sold to residents was substantially cheaper, as it was subsidised by the state.

6 Basically, this describes the soft budget constraint, identified by János Kornai. For details see Kornai, 'A puha költségvetési korlát'. 
of thousands from their jobs in socialist industry and agriculture into the labour market. The Hungarian state governance of the time was incapable of meeting these challenges. In Western Europe and North America regions, however, free working capital and cash funds were available, and East Central Europe, including Hungary, was regarded as a promising area for investment. The Hungarian political leadership conducting the regime change and the corporate sector were stricken by the lack of assets and skills while the Western world was characterised by an excess of capital and skills. The regime change of the Hungarian economy aimed at the alignment of market (demand and supply) conditions, under an excessive demand pressure/need. ${ }^{7}$ Although there were some attempts to rectify this and government schemes to strengthen Hungarian enterprises with weak resource allocation in the market space, all of them failed, a well-capitalised corporate circle did not emerge, and neither did its social reflection, a Hungarian middle class on a social scale, backed by a predictable private property base. ${ }^{8}$ The system was dominated by imported working capital and imported portfolio capital (financial capital) required for further financing government debt. A regulatory practice "familiar" to and favourable to international companies was also imported with this structure, which was "operated" by foreigners since their regulatory policy also seeped (integrated) from their countries of origin into the Hungarian practice. In terms of the technical basis and regulatory methodology, an imported market economy emerged in Hungary, which, as the Soviet-type planned economy launched in 1947, was likewise not the consequence of organic development.

István Stumpf argued that "a normative legislative instrument enabled the process of the regime change to be launched in line with the requirements of the new boundaries of the rule of law and the first democratic, multi-party elections to take place. Even upon closer scrutiny, no coherent principles of state and social philosophy can be detected among the laws preparing the regime change and the scenarios constructed for the regime change". 9 This description of the situation by Stumpf, encapsulated as the "birth defect" of the regime change, has had far-reaching consequences, which can still be felt even today. The Hungarian market economy transition was characterised by its continuously running deficits, which was not even changed by the fact that the country joined the EU. Indeed,

Obviously, foreign working capital was interested in the profitable share of state assets and those with which it used to compete in the market. In this case, they tended to acquire markets.

8 The implementation of the idea of a social market economy was a dominant aspiration of the political elite conducting the regime change and the Hungarian Democratic Forum (Magyar Demokrata Fórum, MDF) in particular. However, its pattern and practice had been put in place in Western Europe, in Germany led by Konrad Adenauer and Ludwig Erhard, and in France under De Gaulle several decades previously, but had been severely eroded by the end of the 20th century. From today's perspective, it is basically impossible to revive a bygone economic and social model on the ruins of socialism. It also raised concerns among intellectuals recognising the situation. See my thoughts written on the occasion of former MDF MP, Dénes Csengey's death: Csaba Lentner, 'Szociális piacgazdaságról és gazdasági függetlenségről. Nekrológ Csengey Dénesért' [On social market economy and economic independence. Obituary for Dénes Csengey]. Hitel: Független Irodalmi és Társadalmi Kritikai Lap 28, no 2 (2015), 101-109.

9 István Stumpf, Erős állam, alkotmányos kormányzás [Strong State, Constitutional Limits] (Budapest: Századvég Kiadó, 2014), 18. 
current account and fiscal deficits got really out of control after $2004 .{ }^{10}$ Coercive measures to improve budgetary and external positions became a regular occurrence, including the economic policy adjustment package of 1995 and the convergence path adjustment launched in the autumn of 2006 (which soon stalled), which focused on increasing the budgetary burdens of the population and small enterprises, that had a limited capacity to promote their own interests, while at the same time dismantling their state subsidies. These programmes shared the feature that they could generate close-to-balance a position temporarily but they caused an economic recession and significant unemployment, while the solvent demand and social benefits for the population also dropped. ${ }^{11}$

One of the main aims of the economic policy of the regime change was to "revamp" via changes in ownership the technological base on which the outdated structure of production was based, which was supposed to culminate in raising foreign working capital to remedy the insufficient capital accumulation in the country. The other component of developing a market economy was the application of a free market institutional system and the implementation of a set of free market principles, and consequently, the dismantling of protectionist instruments protecting the domestic market. New tax laws were introduced to serve these main goals of economic policy, but they had severe social consequences. The wide-ranging tax allowances and state investment aids enjoyed by international companies which relocated their operations in Hungary, providing the backbone of the output of the national economy rendered the budget asymmetrical. On the one hand, they did not contribute to the revenue side of the budget according to their tax capacities (as was allowed by legislation), while on the other hand, they did not sufficiently solve the country's employment problems, as had been hoped at the beginning of the regime change, and they integrated the Hungarian SME sector in their corporate systems only to a moderate extent (as outworkers). ${ }^{12}$ The state budget had been exhausted by the demands of supplying state aids granted to a permanent number of people with a low social status, the demand of Hungarian small companies for subsidies and the interest burden of the government debt, which multiplied sevenfold between 1990 and 2010, and in fact, the deficit was growing. The room for manoeuvre in Hungarian economic policy had chronically shrunk.

10 A collection of essays was published in honour of university professor Ernő Huszti in 2007. Some forty papers by leading fiscal experts and members of the left-wing and right-wing intellectual elite analysed the process of the regime change. None of the authors at that time could describe the preceding one and a half decades as a success story. See Csaba Lentner (ed.), Pénzügy-politikai stratégiák a XXI. század elején [Financial Policy Strategies in the Early 21st Century] (Budapest: Akadémiai Kiadó, 2007), 584.

11 Basically, austerity measures were taken; growth potential was sacrificed for the sake of attaining financial equilibrium.

12 The author of this study does not dispute the innovation impact of international companies on the Hungarian national economy, but unfortunately they have become island-like formations and have failed to lead the economy or society into the circle of developed market economies and welfare societies, although as a result of a more constructive economic policy of recent years, they have formed stronger bonds with the country, especially through their stronger integration in the discharge of public burdens and strategic agreements concluded with the government. Moreover, their role in employment has remained rather limited. 
The economic policy prevailing between 1999 and 2002, the main component of which was the Széchenyi National Development Plan based on and developing endogenous factors, was a breath of fresh air in a harsh market economy transition which had essentially been inspired by neoliberalism. Despite the adverse developments happening in the world - the impact of the Asian crisis in 1997-1998 - the economic development programme, "organised by fiscal measures"13 steered the Hungarian economy onto a growth path, achieving two-and-a-half times the average growth rate of the European Union while simultaneously the government debt and inflation were also reduced. Lending relationships established with the International Monetary Fund practically ceased. ${ }^{14}$ In the years around the turn of the millennium, a period of rapid catching-up could be observed, during which Hungary undoubtedly overtook the other Visegrád countries in terms of GDP per capita. ${ }^{15}$ The loose fiscal policy introduced in 2002, however - following the change of government - led to fiscal imbalances that could not be offset by tightening monetary policy, and Hungary began to lag behind the regional level of development again, ${ }^{16}$ despite the fact that from the middle of the decade the world was experiencing an economic boom. ${ }^{17}$ Not only did the restrictions applied by the central bank fail to offset the effects of the loose fiscal policy, but, based on Leeper's theorem, it was even proven in detail ${ }^{18}$ that neither a monetary policy endeavouring to cut debt by inflation nor one sacrificing growth for price stability was able to counter the effects of the fiscal conduct of excessive spending.

As a result of a poorly organised economic policy, labour market problems intensified. ${ }^{19}$ Wages and employment failed to improve, which generated an enormous need for loans in households, and this need was met by adopting liberal banking laws and supervisory practice (adopting a free banking approach). Households and companies were tempted by foreign currency loans, which were easier to access and cheaper but which carried

13 It was backed by a Hungarian state-owned bank and implemented by under-planning inflation and earmarking, using the generated extra budgetary resources in a targeted way.

14 For the results of the economic policy course related to the development of mostly endogenous factors and the realisation of internal sources of funding "in our own way, organised by ourselves", see György Matolcsy, Élö emlékeink. A Széchenyi Terv világa [Our Living Memories. The World of the Széchenyi Plan] (Budapest: Heti Válasz Kiadó, 2003), 222.

15 Gergely Baksay and Dániel Palotai, 'Válságkezelés és gazdasági reformok Magyarországon, 2010-2016' [Crisis management and economic reforms in Hungary, 2010-2016], Közgazdasági Szemle 64, no 7-8 (2017), 699700 .

16 The average government deficit in the Visegrád region was only half the figure registered for Hungary, and its level decreased in a trend-like manner compared to the Hungarian processes (based on Baksay and Palotai 'Válságkezelés', 700).

17 Gábor Karsai, 'Ciklus és trend a magyar gazdaságban 1990-2005 között' [Cycles and trends in the Hungarian economy, 1990-2005]. Közgazdasági Szemle 53, no 6 (2006), 509-525.

18 Eric M Leeper, 'Equilibria Under 'Active' and 'Passive' Monetary and Fiscal Policies', Journal of Monetary Economics 27, no 1 (1991), 129-147.

19 Károly Fazekas and Ágota Scharle (eds), Nyugdíj, segély, közmunka. A magyar foglalkoztatáspolitika két évtizede, 1990-2010 [From Pensions to Public Works. Hungarian Employment Policy from 1990-2010] (Budapest: Szakpolitikai Elemző Intézet - MTA KRTK Közgazdaságtudományi Intézet, 2012), 306. 
high repayment risks, ${ }^{20}$ and these provided additional financing to offset the economic uncertainty caused by the weakening economic environment and an escape route from higher forint loans, the repayments of which were inherently more difficult to keep up. The growth model maintained by the increasingly indebted public finances and the primary income owning sectors indebted in foreign currency came to a dead end in 2006 and was already becoming unsustainable, ${ }^{21}$ but since the global economic crisis unfolding in $2007-$ 2008 caused an unwelcome change in the rates of the external resources denominated in foreign currency and in their interest rates, the effective inoperability of the budget, the corporate and the household sectors, financed as they were from external sources, became obvious and the country needed international help to avoid national bankruptcy.

The prelude to the situation which unfolded by the autumn of 2008 was the government's intention to adjust the 2006 convergence trajectory, which focused largely on revenues and increased tax burdens on primary income owners while simultaneously reducing their incomes, but, since it hardly made any effort to address structural deficiencies, it was able to alleviate these problems only temporarily. From 2006 to 2007, the budget deficit to GDP decreased from 9.3 to 5.1 per cent, but due to a drop in external resources and the fact that the budget had previously been fuelled by overspending and then tightened, economic growth decreased from 3.9 to 0.4 per cent, while in the rest of the Visegrád region ${ }^{22}$ it was 7 per cent on average over this period. The destructive effects of the world economic crisis found the Hungarian budget in an already exhausted state.

According to the calculations of György Matolcsy, "in the five years between 1998 and 2002, Hungary was the country fastest converging to the EU average in terms of GDP per capita among the new EU Member States in the region, but then in the second five-year cycle between 2003 and 2007 it became the slowest one in integration. In the first five years, we converged to the EU average by 8.8 per cent, and only by 1.1 per cent in the second". ${ }^{23}$ The evolution of the purchasing power of the national currency also reflected the unstable conditions. According to data by Ernő Huszti, ${ }^{24}$ between 1995 and 2002 the purchasing power of the national currency increased by 24.2 per cent (to $75.8 \%$ ), while between

20 Csaba Lentner (ed.), A devizahitelezés nagy kézikönyve [The Great Handbook of Foreign Currency Lending] (Budapest: Nemzeti Közszolgálati és Tankönyv Kiadó, 2015), 611.

${ }^{21}$ Gábor Orbán and György Szapáry, 'Magyar költségvetési politika: quo vadis?' [Hungary’s fiscal policy: Quo vadis?], Közgazdasági Szemle 53, no 4 (2006), 293-309.

22 Slovakia, the Czech Republic, Poland.

23 György Matolcsy, Éllovasból sereghajtó. Elveszett évek krónikája [From Vanguard to Lagman. A Chronicle of Lost Years] (Budapest: Éghajlat Kiadó, 2008), 13. György Matolcsy also describes how, between 2003 and 2007 , in addition to a slowdown in integration, the convergence advantage gained in the previous five years was also lost, and he even suggests that the period between 2003-2007 had more favourable opportunities in terms of external sources.

24 Ernő Huszti, Egy valuta története. A forint forgalma a stabilizációtól az euró elöszobájáig [The Story of a Currency. Forint Circulation between Stabilisation and the Hallway to the Accession to the Euro Area] (Budapest: L'Harmattan, 2011), 160-167. It must also be added that the inflationary conditions generated in part by the high budget deficit compelled monetary policymakers to take a restrictive (compensatory) approach, which led to the strengthening of the price stability mandate and the inflation targeting system. 
2003 and 2010 (taking the data of the first term year as 100\% again) it decreased by 27.3 per cent (to $72.3 \%$ ).

After the turn of the millennium, both government debt and the interest burden increased significantly. Net foreign debt rose from 16.5 per cent of the GDP in 2002 to 28.2 per cent by 2005 . The government debt-to-GDP ratio had increased from 54.6 per cent (in 2002) to 64.1 per cent by 2006 . In this period, Hungary's fiscal deficit was around 7 per cent of its GDP. By 2006, the country's operation had become unsustainable, ${ }^{25}$ and the situation was further aggravated by the crisis of 2007-2008. As a result, a reform in state operation and public finances became a pressing necessity. Following the change of government and the subsequent adoption of a new economic policy in 2010, Hungary no longer received security loans from the World Bank and the International Monetary Fund, and the EUR 12.5 billion borrowed from IMF during the 2008 crisis, the EUR 6.5 billion borrowed from the European Union and the loan package (a drawdown) of EUR 1 billion from the World Bank were repaid. ${ }^{26}$

Due to poor macroeconomic data and an uncertain and contradictory economic environment, in the context of international events in the autumn of 2008, which also led to a loss of confidence in finances, most investors withdrew from the government securities market and numerous manufacturing companies switched to reduced reproduction processes.

During this period, undesirable processes also emerged in the local governmental subsystem of public finances. Following the change of regime, the undermining of the political and economic independence of local governments, declared after the regime change, started almost from the very beginning of the political transition. The government, struggling with budgetary issues, was continuously conferring the performance of duties to the municipalities, but this decentralisation of duties was not followed by a corresponding allocation of resources. An operational deficit evolved, and then - paradoxically - the scale of the accumulated deficit reported was also enormous from 2004. With Hungary's accession to the EU, investment funds became also available to Hungarian local governments, but they could not provide the necessary matching contribution, but, pursuant to a government resolution, local governments were able to take out a loan to "verify" their own contribution, and, through their banks, issue foreign

25 Why was the financing path unsustainable? For details see Iván Bélyácz and Mónika Kuti, 'A makrogazdaság fenntartható finanszírozási pályájának elérhetőségéről' [On the availability of a sustainable financing path for the macro-economy], Közgazdasági Szemle 59, no 7-8 (2012), 781-797.

26 In the summer of 2010, during and after the change of government, requiring a loan from IMF and the WB consortium was on the agenda for years; however, as a condition, the government would have had to abandon its programme based on non-conventional means as well as reverse the measures it had already taken (e.g. abolishing the banking surtax). In the meantime, international credit rating agencies rated Hungary in the unfavourable (not prime) category, and its reputation on the international lending market was very poor. Thus, the government was able to exit the European Union's excessive deficit procedure without any external help, with its tax policy reforms in 2013. The credit line required in the autumn of 2008 was not entirely drawn down, but the amount drawn down was not used in a professional manner (see Csaba Lentner, East of Europe, West of Asia (Paris: L'Harmattan, 2020), Chapters V-VI. 
currency bonds. In taking advantage of this opportunity, however, the local government sector became trapped in a severe debt spiral. After the deterioration of foreign exchange rates in 2008, they drifted to the verge of inoperability, and this problem was only resolved by the government which came to power after $2010 .{ }^{27}$

The "lack of funds in the budget", the lack of future sustainability, the "shadows" of the global financial crisis of 2007-2008 cast on Hungary and, in particular, the government and the central bank's insufficient response to these challenges discouraged the Hungarian society from supporting the neoliberal cause. ${ }^{28}$

\section{THE POST-2010 HUNGARIAN MODEL: ON NON-CONVENTIONAL FOUNDATIONS}

In the period before the global financial crisis of 2007-2008, Hungary was characterised by poorly regulated public finances, flawed and unsustainable fiscal policies, and nontransparent fiscal management. In the autumn of 2006, the government decided to introduce a package of HUF 2,500 billion to adjust the convergence trajectory, but this intervention also ended up in failure. Overspending was financed from external sources. This financing model became dysfunctional. Verifiably, the fiscal practice followed in the period before 2010 became exhausted and was impossible to continue.

After 2010, reforms were introduced and fiscal regulation changed, which was accompanied by the establishment of adequate and effective state control, and a rulebased fiscal policy became the norm. Hungary's Fundamental Law, which entered into force in 2012, raised the issue of public financial responsibility to the constitutional level. ${ }^{29}$ The chapter on public funds in Hungary's constitution contains regulations pertaining to the central budget, government debt, national assets, transparency, public burden sharing, the Central Bank of Hungary, the Fiscal Council and the State Audit Office. The key principle of the chapter is ensuring a balanced, transparent and sustainable

27 Several experts think that state consolidation has also injured the autonomy of local governments. See, for example, Tamás Vasvári, 'Hardening the Budget Constraint: Institutional Reform in the Financial Management of Hungarian Local Governments', Acta Oeconomica 70, no 4 (2020), 571-592. For the debt map of local governments in a European comparison, including the Hungarian consolidated situation, see László Vértesy, 'Debt Management Strategies of Local Governments in the EU', Pro Publico Bono - Magyar Közigazgatás 8, no 1 (2020), 146-169. It is important to note that the entire debt of local governments have been assumed and a considerable part of their functions have been also transferred within the competence of the state.

28 I agree with Professor Norbert Kis on the successful pursuit of economic policy; he considers the issue of social trust essential for building a successful policy approach (Norbert Kis, 'The Role and Impact of Trust on the Operation and Sustainability of the State', Public Finance Quarterly 63, no 3 [2018], 289-302). Without support from the society, especially, if households and companies are adversely affected, it is hardly possible to implement an economic programme. This is related to the 4th element of Dane Rodrik's institutional matrix, that is the necessity of social legitimacy. For further details see Lentner, East of Europe, West of Asia, Chapters I, VII.

29 For the general ethos of the Fundamental Law, see István Stumpf, Reinventing Government. Constitutional Changes in Hungary (Budapest: Gondolat, 2017). 
fiscal management. In the Fundamental Law, the fiscal centre of gravity is the reduction of public debt. Pursuant to Article 36 (4) -(5) of the Fundamental Law, "(4) Parliament may not adopt an Act on the central budget as a result of which (the) state debt would exceed half of the Gross Domestic Product", and "as long as state debt exceeds half of the Gross Domestic Product, Parliament may only adopt an Act on the central budget which provides for state debt reduction in proportion to the Gross Domestic Product". According to section (6): "Any derogation from the provisions of paragraphs (4) and (5) shall only be allowed during a special legal order and to the extent necessary to mitigate the consequences of the circumstances triggering the special legal order, or, in the event of an enduring and significant national economic recession, to the extent necessary to restore the balance of the national economy."

One of the most important components of the fiscal reforms implemented after 2010 is the reduction in labour taxes, while increasing the proportion of consumption and sales taxes, broadening the family tax credit system and levying taxes on extra profit, while imposing taxes on mostly foreign-owned banks and telecommunications companies in a way that is more proportionate to their tax capacity. In addition to tax reforms, the social security system was also reformed. By the end of 2010, the budget deficit caused by mandatory private pension funds had been growing for some time, as a significant part of the pension contributions payable to private pension fund members (obviously) flowed to private funds, and (automatically,) the current revenues available for covering public pension expenditures fell sharply, and the gap thus generated needed to be closed by the central budget. As a solution to the problem, the mandatory pension fund system was abolished, and a significant number of the private pension scheme members returned to the state pension system.

Upon the entry into force of the Fundamental Law, discipline in and control over public finances became stricter. Act LXVI of 2011 on the State Audit Office, a cardinal law, resulted in the expansion of the State Audit Office's audit powers, allowing it to act more efficiently when taxpayers' money is used and in order to protect national assets. ${ }^{30}$ The Fundamental Law raised the Fiscal Council to a body of constitutional status. The Council is a body which supports the legislative work of the National Assembly, performing its tasks in compliance with the Fundamental Law and other statutory regulations. It participates in drafting the Central Budget Act, and, acting in support of the legislative activity of the National Assembly, it reviews and issues an opinion on whether the central budget gives a true and fair view, and is called upon to give its preliminary consent to the approval of the Act on the Central Budget in order to ensure compliance with the so-called public debt rule. ${ }^{31}$ The introduction of the Stability Act contributed to the debt cutting process, while the Act on National Assets provides the legal background for the transparent and

$30 \quad$ László Domokos and Magdolna Holman, 'The Methodological Renewal of the State Audit Office of Hungary in Light of the Protection of Public Funds', Polgári Szemle 13, English Special Issue (2017), 83-99.

31 Árpád Kovács, 'Rule-Based Budgeting: The Road to Budget Stability: The Hungarian Solution', Polgári Szemle 13, English Special Issue (2017), 39-63. 
responsible management of national assets and the preservation and protection of national values. During this period, the consolidation of debt and the subsequent transformation of Hungary's local government system were carried out, in which the relevant provisions of the Stability Act (Act CXCIV of 2011) and of the Act on National Assets (Act CXCVI of 2011) played a part. ${ }^{32}$

The Central Bank of Hungary is Hungary's national bank and is responsible for monetary policy in a way determined by a specific cardinal law (Act CXXXIX of 2013 on the Central Bank of Hungary). The primary aim of the Central Bank of Hungary is to achieve and maintain price stability. Without jeopardising its primary aim, it also supports the economic policy of the Government with the available monetary policy means. The monetary policy which has been pursued since 2013 has played a major role in stimulating economic growth, through both the Funding for Growth scheme and by encouraging commercial banks to lend more actively. The continuous reduction of the central bank's base rate helped the interest rate conditions for both financing government debt and lending by commercial banks, as the financing of government debt and bank's interest rates became cheaper. The central bank operates on a macroeconomic level and in a social context, and one of the major achievements of the latter focus was the consolidation of corporate foreign currency loans (within the framework of Pillar 2 of the Funding for Growth scheme) and households' foreign currency loans to the detriment of the reserves of the central bank. The resulting change of the monetary regime ended the previously homogeneous practice, pursued since 1987 (with an "inclination" to gradually withdrawing from the refinancing of the real sector and government debt), which had limited the central bank only to the management of inflation. ${ }^{33}$

The immediate crisis management measures taken and the regulatory changes made after the spill-over of the crisis in $2008^{34}$ were incapable of tackling the problem of households' foreign currency loans adequately. The solution was the complete phasing out of household foreign currency loans and mortgage loans denominated in foreign currency, which began in the autumn of $2014 .^{35}$ The conversion from foreign currencies into Hungarian forints took place at the earliest opportunity when it was legally possible and economically

32 For details on the consolidation of local governments see Csaba Lentner and Szilárd Hegedüs, 'Local SelfGovernments in Hungary: Recent Changes through Central European Lenses', Central European Public Administration Review (CEPAR) 17, no 2 (2019), 51-72.

33 For the achievements of the monetary policy after 2013 see György Matolcsy, Egyensúly és növekedés - 20102019. Sereghajtóból újra éllovas [Balance and Growth - 2010-2019. From Lagman into Vanguard Again], second, revised edition (Budapest: Magyar Nemzeti Bank, 2019), 702.

34 Csaba Lentner, 'A gazdasági válság hatása a globális, uniós és hazai szabályozási környezetre’ [The impact of the economic crisis on the regulatory environment in the world, the European Union and Hungary], in A gazdasági világválság hatása egyes jogintézményekre Magyarországon és az Európai Unióban. Interdiszciplináris és jogösszehasonlitó elemzés [The impact of the global financial crisis on specific legal institutions in Hungary and the European Union. An interdisciplinary and comparative analysis], ed. by Âdám Auer and Tekla Papp (Budapest: Nemzeti Közszolgálati Egyetem, 2016), 45-84.

35 On taxonomical aspects see Csaba Lentner, 'The Structural Outline of the Development and Consolidation of Retail Foreign Currency Lending', Public Finance Quarterly 60, no 3 (2015), 297-311. 
viable. ${ }^{36}$ By 2014 the reserves of the MNB had reached a level that guaranteed the safe implementation of the conversion. At the end of September 2014, the portfolio of household foreign currency loans and mortgage loans denominated in foreign currency amounted to HUF 3,350 billion (EUR 10.8 billion) in the banking system. A portfolio of EUR 9 billion was subject to conversion. Banks covered almost the entire portfolio of foreign currency loans converted through the tenders of the Central Bank of Hungary. ${ }^{37}$

The coordination of fiscal and monetary policies was indispensable for economic growth. A monetary turnaround took place in Hungary in 2013 and after that monetary policy played a more proactive role in fuelling economic growth, in addition to ensuring price stability. As a result of a gradual reduction in the base rate (from 7 to 0.9 per cent by 2016 and in the first step to 0.75 per cent and then to 0.6 per cent in the summer of 2020), the financing costs of the private sector fell, and investment and consumption picked up. After 2013, the Central Bank of Hungary launched several schemes to strengthen financial stability and boost economic growth, including the Funding for Growth scheme, the aim of which was to re-establish corporate lending. Between 2013 and 2017 this scheme increased the GDP by $2-2.5$ percentage points, ${ }^{38}$ and it has been instrumental in fuelling growth ever since. ${ }^{39}$ From 2014-2016, the Hungarian state repaid foreign currency debts of nearly EUR 11 billion from forint issues, and a significant number of strategic sectors (mainly public utilities), which had been privatised under duress in the 1990s, were re-acquired as national assets. The processes of the state economy have been heading in the opposite direction since 2010. However, it is necessary to say, despite our successes that the fundamentally changing fiscal and monetary policy has been consistent with international organisations with a strong criticism. From the beginning of the public financial reform, the effects of tax reforms have enforced and from 2013 the intensive monetary policy of the Hungarian National Bank also contributed to the consolidation. These criticisms alighted, maybe there are more a praise word, still present. We are currently missing partial failure of structural reforms. It is a fact that the previous decade was successful for us, which also increases our chances under Covid-19. ${ }^{40}$

36 Péter Pál Kolozsi, Ádám Banai and Balázs Vonnák, 'Phasing out Household Foreign Currency Loans: Schedule and Framework', Financial and Economic Review 14, no 3 (2015), 60-87.

37 On the emergence of foreign currency lending and the need for consolidation see Levente Kovács, 'A devizahitelek háttere' [The background of foreign currency loans], Hitelintézeti Szemle 12, no 3 (2013), 183193.

38 György Matolcsy and Dániel Palotai, 'Hungary is on the Path to Convergence', Financial and Economic Review 18 , no 3 (2019), 5-28.

39 Kolozsi et al., 'Phasing out Household Foreign Currency Loans'.

40 See more in OECD Economic Surveys, 'Hungary', July 2021 and International Monetary Fund, 'IMF Country Report No. 21/135, Hungary', June 2021. 


\section{SUMMARY - A MESSAGE TO THE FUTURE}

The internal market components of the planned economy ${ }^{41}$ were pushed into the background during the market economy transition inspired by neoliberalism, and a radically new model imported largely from Anglophone countries and equipped with content elements, including capital and regulation, was adopted as the way forward. The most important characteristics of the realistic but harsh market economy, which emerged in Hungary from the late 1980s, was an economy founded on private ownership, mainly using foreign working capital due to a lack of or in lieu of sufficient internal resources, the rules of which were introduced without an adequate adaptation period. All this took place alongside increasing indebtedness, mostly because foreign enterprises doing business in Hungary were taxed below their taxation capacities and the domestic sector was poorly funded, which led to the financial stability of the country continuing to deteriorate, although the country, as a result of the EU integration process, became a full member of the European Union in 2004 .

The economic policy implemented between 2010 and 2019 can be regarded as the most successful of the past 100 years, within the framework of which the budgetary and external balance improved considerably, while simultaneously seeing the start of economic growth (see Figure 1). The foundations of the model behind the results are fiscal discipline ensured by strict statutory regulations and a stringent control environment, the expansion of public burden bearing and a focus on the Central Bank's policy to support growth and stability, accompanied by measures to increase the solvent demand of the population and preserve purchasing power, making society "interested" in the growth path. ${ }^{42}$ In effect, an active state-led economic policy was implemented, under market economy conditions. Between 2010 and 2019, the general government debt-to-GDP ratio decreased from 85 per cent to 65 per cent, the net external debt decreased from 55 per cent to 10 per cent, and the share of foreign debt within government debt decreased from 65 per cent to 30 per cent.

Another positive element of the period between 2010 and 2019 is that social-type income growth, increasingly unbacked by any economic performance under Kádár's regime and then expanded to a broad circle of people during the market economy transition, where it became a major form of making a living in certain groups of society, was reined in, as the policymakers tried to eradicate the social benefit-based society. ${ }^{43}$

${ }^{41}$ Small-scale farms, widespread in the form of agricultural cooperatives, and the ways of production based on the land allotted to the workers of state farms, rudimentary enterprises based on the small concessions of stateand cooperative-owned property as well as economic work teams "had melted" by the time of the regime change. Small enterprises, established under Act VI of 1988 (the Corporate Act) and enterprises with a so-called Start Loan and established under employee shareholding schemes mostly met the same fate.

42 The family tax allowance, the Family and Housing Support and other beneficial social measures are the positive feedback to the people ("encouragements") of an economy put on a growth trajectory.

43 These theses may also correspond to Péter Mihályi's concept exclusively emphasising market conditions, but it is important to note that while Mihályi regards the completion of market conditions justified in an almost exclusive and comprehensive manner, the main point of my work and my other research findings 
In order to maintain full employment, guaranteed by the socialist planned economy system, the leadership of the time - as the performance of work was deteriorating - took out foreign loans to sustain loss-making companies and shore up inefficient workplaces. The loan taken out by the state was practically distributed freely among the population, and ultimately, this system continued to function. The philosophy and conduct (attitude) of the workforce, based on not particularly high work efficiency and a collective share in loans survived the regime change, which was even further promoted by deregulation, an inefficient economic policy and a policy of encouraging commercial banks to "overlend" to borrowers. In addition to government debt, the post-transition period saw the appearance of local government debt, and, in particular, an excessive use of credit by households or individuals. This conduct of taking out such loans carelessly (without any borrowing power), without thoroughly considering how they would be repaid, particularly among the population, can be regarded as the legacy of Kádár's regime, which resulted in the non-repayment of loans on both the household and local governmental levels. The state acted as a consolidator both for local governments and households after $2010,{ }^{44}$ but after this financial bail-out stringent regulations and controls preventing indebtedness were adopted. This consistent, controlled rule-based ethos has become one of the main characteristics of the economic policy, which became active rather than passive in nature.

Considering the analysis of seven decades, encompassing three economic approaches, and within those, focusing on the last thirty years, it can be concluded that good fiscal policy should be simultaneously based on the economic historical background of the country, aligned to the needs of the prevailing market and social forces, particularly internal (endogenous) factors, while following international progressive trends. A sense of perspective is important when considering how to fulfil these triple requirements, since, for example, international trend-following cannot be given priority over the economic historical background, or to the detriment of internal market players or social operators. No economic policy approaches can be forced onto a country, as this disrupts the harmony and optimal functioning of production conditions and productive forces, and indifference and lack of motivation will prevail in both the corporate and the employee sectors.

Taking all this into consideration, the policy approach followed from 2010-2019 can be characterised as highly effective, since it basically aims at meeting internal needs optimally,

published is that an adequate transition period should be ensured and market considerations cannot be applied to the entire sphere of corporations, households and public finances. A kind of social sensitivity must be demonstrated, either due to the historical background or the "fragmentation" of certain layers of society. For Mihályi's concept, see Péter Mihályi and Iván Szelenyi, 'The Two Forms of Modern Capitalism: Liberal and Illiberal States. A Criticism of the Varieties of Capitalism Paradigm', Comparative Sociology 19, no 2 (2020), 155-175; Péter Mihályi, Diszkriminativ, piac- és versenyellenes állami gazdaságpolitika Magyarországon, 2010-2015 [Discriminative anti-market and anti-competitive state economic policy in Hungary, 2010-2015] (Budapest: MTA KRTK Közgazdaságtudományi Intézet/Institute of Economics, Centre for Economic and Regional Studies of the Hungarian Academy of Sciences, 2016).

44 That is, the soft budget constraint, formulated by János Kornai, continued to prevail, which was heavily criticised by Kornai (see his works cited). 
with a focus on the income growth of the society, and simultaneously following detectable trends of the international arena, by, for example, applying a more robust state control or implementing the central bank's non-conventional crisis management. The components of the post-2010 model are largely similar to the policies pursued following the AustroHungarian Compromise of $1867 .^{45}$

The continuity of the current course, i.e. its resilience, will be provided and proven by the responses given to the crisis which began in the spring of $2020 .{ }^{46}$ The economic downturn caused by Covid-19 is not the consequence of the fiscal policy followed by Hungary or the earlier operation of the central bank, but of an external factor - the global pandemic. During crisis management, both public financial institutions have pursued an active policy stimulating demand and have made efforts to mitigate the adverse consequences of the crisis. ${ }^{47}$ Nevertheless - demonstrating the severity of the crisis ${ }^{48}$ - Hungary's GDP fell by 13.6 per cent, the volume of industrial production plummeted by 25 per cent, the tourism sector shrank by 80 per cent and the hospitality sector by 60 per cent in Q2 of 2020 . A similar, although smaller decline is expected for Q3 and Q4 of 2020 and even for the first six months of 2021, and as a result, the GDP of Hungary is likely to decline for 2020 as well as 2021, which will certainly weaken the fiscal stability of the state. The overall government debt-to-GDP ratio, which had decreased from 85 per cent to 65 per cent in nine years, soared up to 85 per cent again within a year. Instead of, or besides the competitiveness strategy, safety-oriented debt management is expected to come increasingly to the fore (again) (see Figure 1 for the growth path of 1996-2020).

Regarding crisis management, it should be noted that the economic policy of the period between 2010 and 2019 was fundamentally satisfactory but not in all aspects. The largescale implementation of the Competitiveness Programme, launched by the Central Bank of Hungary in 2017, started at a lower speed than expected in the years preceding the pandemic crisis. The economies of scale of small enterprises were not developed, the fusions it was supposed to encourage did not materialise, personal income tax did not become a one-digit number, corporate tax did not decrease further by fiscal means and through representation by chambers of commerce and industry. As a result, helping out fragmented small enterprises in a crisis consumes several orders of magnitude more public funds than it might. Fixed income-type taxes dampened the (investment) solvent demand of households and corporations; therefore, the crisis management measures

45 For the economic system of the dualist state model see Lentner, East of Europe, Chapter II.

46 The dualist economic model was caused by World War I, that of Bethlen's consolidation was caused by World War II, that of the planned economy was caused by the arms race of the Cold War and the increasingly severe and complex issues of the planned economy. That of the market economy transition (the period lasting until 2010) was caused by an economic model imported and applied without proper consideration (see the logic of Lentner, East of Europe).

47 Since 2010 the Hungarian practice has been following a version of the active policy stimulating demand, developed by J M Keynes.

48 According to the forecast of the World Bank, the global economy is currently facing a crisis which is two and a half times more severe than that of the 2007-2008 was. 
of both the Central Bank and the government "cost more" amidst the current crisis, leading to the present situation where Hungary is not top ranking in terms of international convergence or, consequently, the efficiency of crisis management. ${ }^{49}$ If these competitiveness measures had been taken, both the household and the corporate sector would have had improved capitalisation, and a lesser need for state bail-out would have arisen. ${ }^{50}$

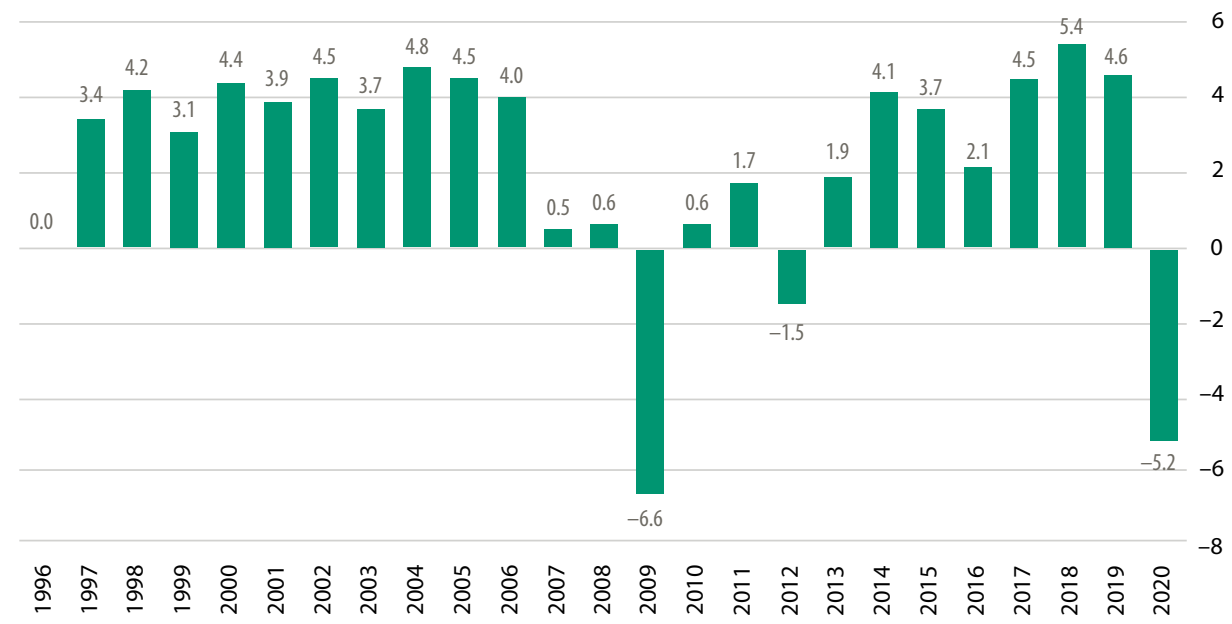

Figure 1 - Annual growth rate of Hungary's GDP (\%)

Source: Hungarian Central Statistical Office.

Considering the international arena: between 2009 and 2020 Estonia caught up from 64.6 per cent of the EU average to almost 84 per cent, catching up to the level of developed European countries by nearly 20 percentage points. Only Lithuania was capable of an even faster rate of convergence. Hungary was able to close the gap by only 10 per cent. In the case of Estonia, its accumulated growth of 40 per cent is also outstanding, two-thirds of which was generated by services. The Estonians carried out a service-based re-industrialisation, which was built upon the IT sector and a comprehensive digital transition, involving especially the public sector. In addition, they achieved the EU's third highest investment

49 One can agree with László Csaba’s criticisms of the ruling political system on several points. He had referred to the weak efficiency of the Hungarian economic policy in an international context much earlier. (For example see László Csaba, 'Unorthodoxy in Hungary: an Illiberal Success Story?' Post-Communist Economies (2019); László Csaba, 'Illiberális kapitalizmus' [Illiberal Capitalism], in Gazdasági, politikai és társadalmi kihívások a 21. században. Ünnepi kötet a 65 éves Halmai Péter tiszteletére [Economic, Political and Social Challenges in the $21^{\text {st }}$ Century. A Celebratory Volume in Honour of 65-Year-Old Péter Halmai], ed. by Tamás Halm, Hilda Hurta and Boglárka Koller (Budapest: Dialóg Campus, 2018), 95-103.

50 All these suggest that the set of goals and the toolkit of fiscal and monetary public financial institutions should not only converge in the same direction but also at the same speed. In this case, monetary hyperactivity was not followed by the intensity of the fiscal policy, instead, its measures slowed down. 
rate on a 10 -year average with a level of over 25 per cent, while unemployment dropped from 16 per cent to 4 per cent. Lithuania was even more successful than Estonia in this respect, rising from 56.9 per cent to around 84 per cent, improving their arrears by 27 percentage points. Romania ranked number 3 of the 9 Eastern and Central European countries; they had risen from 52.2 per cent in 2009 to nearly 70 per cent by the end of 2019. Latvia came closer to the EU average by 16 percentage points, Poland did so by 13 percentage points. In this ranking, Hungary takes sixth place, then comes the Czech Republic, both with a catch-up performance of less than 10 per cent. Measured on its own historical basis, the Hungarian growth path between 2010-2019 was successful, but it is at the bottom of the middle pack in an international comparison, ${ }^{51}$ which may largely be due to the lack of development of economies of scale in the small enterprise sector ${ }^{52}$ and an untimely halt in tax competitiveness.

${ }_{51}$ Slovenia and Slovakia have an even less favourable catching-up record than Hungary.

52 Hungarian micro and small enterprises are not able to export enough, the minimum wage is also a problem in many cases and they cannot employ a highly qualified workforce, which would be the basis for the renewal of their production and technical base and export capacity. The Hungarian SME sector employs 75 per cent of the workforce, but accounts for only 40 per cent of GDP, while it accounts for just 20 per cent of investment in the national economy. This series of numbers in itself suggests an inefficient structure. 


\section{REFERENCES}

1. Baksay, Gergely and Dániel Palotai, 'Válságkezelés és gazdasági reformok Magyarországon, 2010-2016' [Crisis management and economic reforms in Hungary 2010-2016]. Közgazdasági Szemle 64, no 7-8 (2017), 698-722. Online: https:/doi.org/10.18414/ KSZ.2017.7-8.698

2. Bélyácz, Iván and Mónika Kuti, 'A makrogazdaság fenntartható finanszírozási pályájának elérhetöségéről' [On the availability of a sustainable financing path for the macro-economy]. Közgazdasági Szemle 59, no 7-8 (2012), 781-797.

3. Csaba, László, 'Illiberális kapitalizmus' [Illiberal Capitalism], in Gazdasági, politikai és társadalmi kihívások a 21. században. Unnnepi kötet a 65 éves Halmai Péter tiszteletére [[Economic, Political and Social Challenges in the $21^{\text {st }}$ Century. A Celebratory Volume in Honour of 65-Year-Old Péter Halmai], ed. by Tamás Halm, Hilda Hurta and Boglárka Koller. Budapest: Dialóg Campus, 2018, 95-103. Online: https://doi. org/10.1556/2065.180.2019.8.15

4. Csaba, László, 'Unorthodoxy in Hungary: an Illiberal Success Story?' Post-Communist Economies (2019). Online: https://doi.org/10.1080/14631377.2019.1641949

5. Domokos, László and Magdolna Holman, 'The Methodological Renewal of the State Audit Office of Hungary in Light of the Protection of Public Funds'. Polgári Szemle 13, English Special Issue (2017), 83-99. Online: https://doi.org/10.24307/psz.2017.0306

6. Huszti, Ernő, Egy valuta története. A forint forgalma a stabilizációtól az euró elöszobájáig [The Story of a Currency. Forint Circulation between Stabilisation and the Hallway to the Accession to the Euro Area]. Budapest: L'Harmattan, 2011.

7. International Monetary Fund, 'IMF Country Report No. 21/135, Hungary', June 2021. Online: https://doi.org/10.5089/9781513584430.002

8. Karsai, Gábor, 'Ciklus és trend a magyar gazdaságban 1990-2005 között' [Cycles and trends in the Hungarian economy, 1990-2005]. Közgazdasági Szemle 53, no 6 (2006), 509525 .

9. Fazekas, Károly and Ágota Scharle (eds), Nyugdij, segély, közmunka. A magyar foglalkoztatáspolitika két évtizede, 1990-2010 [From Pensions to Public Works. Hungarian Employment Policy from 1990-2010]. Budapest: Szakpolitikai Elemző Intézet - MTA KRTK Közgazdaságtudományi Intézet, 2012.

10. Kis, Norbert, 'The Role and Impact of Trust on the Operation and Sustainability of the State'. Public Finance Quarterly 63, no 3 (2018), 289-302.

11. Kolozsi, Pál Péter, Ádám Banai and Balázs Vonnák, 'Phasing out Household Foreign Currency Loans: Schedule and Framework'. Financial and Economic Review 14, no 3 (2015), 60-87.

12. Kornai, János, 'A szocialista rendszer' [The Socialist Regime], in Kornai János válogatott munkái II [The Selected Works of János Kornai Vol. II]. Pozsony: Kalligram, 2012.

13. Kornai, János, 'A puha költségvetési korlát' [The Soft Budget Constraint], in Kornai János válogatott munkái IV [The Selected Works of János Kornai Vol. IV]. Pozsony: Kalligram, 2014. 
14. Kovács, Árpád, 'Rule-Based Budgeting: The Road to Budget Stability: The Hungarian Solution'. Polgári Szemle 13, English Special Issue (2017), 39-63. Online: https://doi. org/10.24307/psz.2017.0304

15. Kovács, Levente, 'A devizahitelek háttere' [The background of foreign currency loans]. Hitelintézeti Szemle 12, no 3 (2013), 183-193.

16. Leeper, Eric M, 'Equilibria Under 'Active' and 'Passive' Monetary and Fiscal Policies'. Journal of Monetary Economics 27, no 1 (1991), 129-147. Online: https:/doi. org/10.1016/0304-3932(91)90007-B

17. Lentner, Csaba (ed.), Pénzügy-politikai stratégiák a XXI. század elején [Financial Policy Strategies in the Early $21^{\text {st }}$ Century]. Budapest: Akadémiai Kiadó, 2007.

18. Lentner, Csaba, 'Szociális piacgazdaságról és gazdasági függetlenségről. Nekrológ Csengey Dénesért' [On social market economy and economic independence. Obituary for Dénes Csengey]. Hitel: Független Irodalmi és Társadalmi Kritikai Lap 28, no 2 (2015), 101-109.

19. Lentner, Csaba (ed.), A devizahitelezés nagy kézikönyve [The Great Handbook of Foreign Currency Lending]. Budapest: Nemzeti Közszolgálati és Tankönyv Kiadó, 2015.

20. Lentner, Csaba, 'The Structural Outline of the Development and Consolidation of Retail Foreign Currency Lending'. Public Finance Quarterly 60, no 3 (2015), 297311.

21. Lentner, Csaba, 'A gazdasági válság hatása a globális, uniós és hazai szabályozási környezetre' [The impact of the economic crisis on the regulatory environment in Hungary, the European Union and the world], in A gazdasági világválság hatása egyes jogintézményekre Magyarországon és az Európai Unióban. Interdiszciplináris és jogösszehasonlitó elemzés [The impact of the global financial crisis on specific legal institutions in Hungary and the European Union. An interdisciplinary and comparative analysis], ed. by Ádám Auer and Tekla Papp. Budapest: Nemzeti Közszolgálati Egyetem, 2016, 45-84.

22. Lentner, Csaba and Szilárd Hegedűs, 'Local Self-Governments in Hungary: Recent Changes through Central European Lenses'. Central European Public Administration Review (CEPAR) 17, no 2 (2019), 51-72. Online: https://doi.org/10.17573/cepar.2019.2.03

23. Lentner, Csaba, East of Europe, West of Asia. Paris: L'Harmattan, 2020.

24. Matolcsy, György, Élö emlékeink. A Széchenyi Terv világa [Our Living Memories. The World of the Széchenyi Plan]. Budapest: Heti Válasz Kiadó, 2003.

25. Matolcsy, György, Éllovasból sereghajtó. Elveszett évek krónikája [From Vanguard to Lagman. A Chronicle of Lost Years]. Budapest: Éghajlat Kiadó, 2008.

26. Matolcsy, György and Dániel Palotai, 'Hungary is on the Path to Convergence'. Financial and Economic Review 18, no 3 (2019), 5-28. Online: https://doi.org/10.33893/ FER.18.3.528

27. Matolcsy, György, Egyensúly és növekedés - 2010-2019. Sereghajtóból újra éllovas [Balance and Growth, 2010-2019. From Lagman into Vanguard Again], second, revised edition. Budapest: Magyar Nemzeti Bank, 2019. 
28. Mihályi, Péter, Diszkriminatív, piac- és versenyellenes állami gazdaságpolitika Magyarországon, 2010-2015 [Discriminative anti-market and anti-competitive state economic policy in Hungary, 2010-2015]. Budapest: MTA KRTK Közgazdaságtudományi Intézet/Institute of Economics, Centre for Economic and Regional Studies of the Hungarian Academy of Sciences, 2016.

29. Mihályi, Péter and Iván Szelenyi, 'The Two Forms of Modern Capitalism: Liberal and Illiberal States. A Criticism of the Varieties of Capitalism Paradigm'. Comparative Sociology 19, no 2 (2020), 155-175. Online: https://doi.org/10.1163/15691330-BJA10006

30. OECD Economic Surveys, 'Hungary', July 2021. Online: www.oecd.org/economy/ surveys/Hungary-2021-OECD-economic-survey-overview.pdf

31. Orbán, Gábor and György Szapáry, 'Magyar költségvetési politika: quo vadis?' [Hungary's fiscal policy: Quo vadis?] Közgazdasági Szemle 53, no 4 (2006), 293-309.

32. Stumpf, István, Erös állam, alkotmányos kormányzás [Strong State, Constitutional Limits]. Budapest: Századvég Kiadó, 2014.

33. Stumpf, István, Reinventing Government. Constitutional Changes in Hungary. Budapest: Gondolat, 2017.

34. Vasvári, Tamás, 'Hardening the Budget Constraint: Institutional Reform in the Financial Management of Hungarian Local Governments'. Acta Oeconomica 70, no 4 (2020), 571-592. Online: https://doi.org/10.1556/032.2020.00037

35. Vértesy, László, 'Debt Management Strategies of Local Governments in the EU'. Pro Publico Bono - Magyar Közigazgatás 8, no 1 (2020), 146-169. Online: https:// doi.org/10.32575/ppb.2020.1.8

Csaba Lentner, PhD habil, is a Full Professor at the Faculty of Governmental and International Studies of the University of Public Service. A dedicated researcher and expert of public finances and banking regulation. An advocate of a new kind of economic thinking and the academic articulation of unconventional economic practices. 